\title{
Spatial variability of particle-attached and free-living bacterial diversity in surface waters from the Mackenzie River to the Beaufort Sea (Canadian Arctic)
}

\author{
E. Ortega-Retuerta ${ }^{1,2, *}$, F. Joux ${ }^{1,2}$, W. H. Jeffrey ${ }^{3}$, and J. F. Ghiglione ${ }^{1,2}$ \\ ${ }^{1}$ UPMC Univ Paris 06, UMR7621, Laboratoire d'Océanographie Microbienne, Observatoire Océanologique, \\ 66650 Banyuls/mer, France \\ ${ }^{2}$ CNRS, UMR7621, Laboratoire d'Océanographie Microbienne, Observatoire Océanologique, \\ 66650 Banyuls/mer, France \\ ${ }^{3}$ Center for Environmental Diagnostics and Bioremediation, University of West Florida, Pensacola, FL, USA \\ * present address: Departament de Biologia Marina i Oceanografia, Institut de Ciències del Mar-CSIC, Barcelona, Spain \\ Correspondence to: E. Ortega-Retuerta (ortegaretuerta@icm.csic.es) and J. F. Ghiglione (ghiglione@ obs-banyuls.fr)
}

Received: 15 November 2012 - Published in Biogeosciences Discuss.: 10 December 2012

Revised: 25 March 2013 - Accepted: 1 April 2013 - Published: 25 April 2013

\begin{abstract}
We explored the patterns of total and active bacterial community structure in a gradient covering surface waters from the Mackenzie River to the coastal Beaufort Sea in the Canadian Arctic Ocean, with a particular focus on free-living (FL) vs. particle-attached (PA) communities. Capillary electrophoresis-single-strand conformation polymorphism (CE-SSCP) showed significant differences when comparing river, coast and open sea bacterial community structures. In contrast to the river and coastal waters, total (16S rDNA-based) and active (16S rRNA-based) communities in the open sea samples were not significantly different, suggesting that most present bacterial groups were equally active in this area. Additionally, we observed significant differences between PA and FL bacterial community structure in the open sea, but similar structure in the two fractions for coastal and river samples. Direct multivariate statistical analyses showed that total community structure was mainly driven by salinity (a proxy of dissolved organic carbon and chromophoric dissolved organic matter), suspended particles, amino acids and chlorophyll $a$. Pyrosequencing of 16S rRNA genes from selected samples confirmed significant differences between river, coastal and sea samples. The PA fraction was only different ( $15.7 \%$ similarity) from the FL one in the open sea sample. Furthermore, PA samples generally showed higher diversity (Shannon, Simpson and Chao indices) than FL samples. At the class level, Opitutae
\end{abstract}

was most abundant in the PA fraction of the sea sample, followed by Flavobacteria and Gammaproteobacteria, while the FL sea sample was dominated by Alphaproteobacteria. Finally, for the coast and river samples and both PA and FL fractions, Betaproteobacteria, Alphaproteobacteria and Actinobacteria were dominant. These results highlight the coexistence of particle specialists and generalists and the role of particle quality in structuring bacterial communities in the area. These results may also serve as a basis to predict further changes in bacterial communities should climate change lead to further increases in river discharge and related particle loads.

\section{Introduction}

The Arctic Ocean is subject to profound changes due to global warming (Corell and Cleveland, 2010; Wassmann et al., 2011). On the one hand, increases in temperature, a reduction in the extension of the ice pack and prolonging of ice-free periods (Perovich, 2011) and changes in the light field will change the abundance, activity and distribution of primary producers, as well as the duration and timing of phytoplankton blooms (Arrigo and van Dijken, 2004; Lavoie et al., 2010). On the other hand, river runoff has increased by $7 \%$ in the last $60 \mathrm{yr}$ due to higher precipitation and glacier 
melting (Peterson et al., 2002). This last fact will increase the importance of riverine nutrient inputs, which will in turn sustain primary and secondary production in an area that already receives $10 \%$ of the global river discharge (Dittmar and Kattner, 2003). This is especially important in the eastern Beaufort shelf (coastal Arctic Ocean). This area receives approximately 128 tons of sediment particles per year from the Mackenzie River, which is the main source of particles and brings $95 \%$ of the shelf sediment supply (Macdonald et al., 1998). Additionally, Arctic warming contributes to the increase of soil organic carbon in the Arctic rivers due to permafrost melting (Guo and Macdonald, 2006). Autochthonous particulate organic matter ( $\mathrm{POM}$ ) inputs can be high in the area coincident with the occurrence of phytoplankton blooms associated with the retreat of sea ice (Forest et al., 2008). These contrasting sources lead to a composite of inorganic and organic suspended materials of diverse origin and physico-chemical properties, which may be subject to substantial alteration in size and chemical composition.

Marine particles have been identified as "hotspots" of high microbial abundance and activity (Smith et al., 1992; Azam et al., 1994). Particle-attached (PA) bacteria can show higher specific metabolic activity (Mével et al., 2008) and higher enzymatic activity rates (Murrell et al., 1999) than their freeliving (FL) counterparts. In addition, elevated enzymatic activity on particles may release nutrients to the surrounding water, creating hot spots of high microbial activity around them (Azam and Malfatti, 2007). The contribution of the PA fraction to the total bacterial activity is highly variable, but can be as high as $90 \%$ of the total bacterial production in estuarine habitats (Crump et al., 1998). This contribution depends mainly on the concentration of attached bacteria and on the size, quantity and quality of the suspended particles. For instance, a previous experimental study showed higher bacterial growth associated with organic than with mineral particles (Kernegger et al., 2009). In the Beaufort Sea, previous studies have highlighted the importance of bacteria degrading POM in aggregates (Kellogg et al., 2011; Forest et al., 2012) and reported high variability (from 0 up to $98 \%$ ) of the contribution of PA bacteria to total bacterial production (Garneau et al., 2009).

Whether particles can host a distinct microbial community (Acinas et al., 1997; Rath et al., 1998) is still unclear, as some studies have reported a high degree of specialization of PA bacteria (Acinas et al., 1999; Crump et al., 1999; Ghiglione et al., 2009), while others have proposed that the majority of bacterial groups are ubiquitous and exchange from FL to PA lifestyles (Hollibaugh et al., 2000; Ghiglione et al., 2007). Previous studies in Arctic and subarctic regions have found different bacterial communities in PA fractions from those in FL (Hodges et al., 2005; Garneau et al., 2009; Lapoussiere et al., 2011), although clear niche segregation between the two fractions has not always been observed (Hollibaugh et al., 2000). Owing to the different metabolic capacities (e.g., different enzyme sets) associ- ated with different bacterial populations, exploring patterns of bacterial community structure in different particle fractions (i.e., particle-attached vs. free-living) can give us hints about major metabolic pathways, and hence help understand nutrient fluxes and elemental cycles.

If a complex spatio-temporal variability of substrate facilitates the diversification of bacteria by different physiological adaptations to the environment, bacterial diversity is expected to be high in coastal environments influenced by river outflows, where abrupt changes in salinity, temperature and substrate quality, including particles, may lead to diverse habitats and niche differentiation (Crump et al., 1999). A change in river discharge and sediment load will also likely impact the dynamics of PA and FL bacterial communities in the area.

In the present study we describe summer bacterial diversity and community structure in surface waters from the Mackenzie River to the Beaufort Sea in the Canadian Arctic. During this time, surface waters had the maximum of bacterial activity (Ortega-Retuerta et al., 2012b). We evaluated spatial differences in community structure from the river to the open sea, separating them into free-living vs. particleattached bacterial communities. For our purposes, we combined the use of molecular fingerprinting and 454-tag pyrosequencing based on 16S rRNA genes. As metabolically active bacteria contain more rRNA than resting or starved cells (Kemp et al., 1993), we compared 16S rDNA vs. 16S rRNA community structure in order to address which members of the bacterial community are metabolically active.

\section{Material and methods}

\subsection{Sampling}

The MALINA campaign was carried out in the southern Beaufort Sea, Arctic Ocean, in late summer, from 30 July to 27 August 2009 aboard the research icebreaker CCGS Amundsen. The study area presented high ice concentration when compared with previous years in the same period (Forest et al., 2012). The Mackenzie River maximum discharge usually occurs at the end of spring (June-July), decreasing thereafter (Doxaran et al., 2012).

For this study, surface waters from 20 stations were selected along two transects from the Mackenzie River mouth to the open sea (bottom depth $1538 \mathrm{~m}$ ) (Fig. 1). Correspondence between station codes and numbers in the general MALINA sampling grid are detailed in supplemental Table 1. In the Mackenzie River mouth, water was collected manually from a zodiac (top-surface, 0 to $0.5 \mathrm{~m}$ deep) using clean 5liter carboys. For other stations, water was collected from 3 to $3.5 \mathrm{~m}$ depth using PVC bottles (12 $\mathrm{L}$ each, Ocean Test) mounted on a SBE Rosette equipped with a SBE911-plus CTD profiler. 
Table 1. Average and range of primary physical, chemical and biological parameters in the different sections of the study area. Temp: temperature. Sal: salinity. SPM: suspended particulate matter. $\mathrm{NO}_{3}$ : nitrate concentration. $\mathrm{NH}_{4}$ : ammonium concentration. $\mathrm{PO}_{4}$ : phosphate concentration. Si: silica concentration. DOC: dissolved organic carbon concentration. DON: dissolved organic nitrogen concentration. TDAA: total dissolved amino acids concentration. DOP: dissolved organic phosphorus concentration. POC: particulate organic carbon concentration. PON: particulate organic nitrogen concentration. POP: particulate organic phosphorus concentration. CDOM: chromophoric dissolved organic matter absorption. Chl $a$ : chlorophyll $a$ concentration. BP: bacterial production. \% PA BP: percentage of particle-attached bacterial production. Non-parametric Mann-Whitney $U$ tests were performed to check statistical differences in the presented variables between river and coast samples and between coast and open sea samples $(* p<0.05, * * p<0.01$, ***p $<0.001)$.

\begin{tabular}{llll}
\hline Parameter & River $(n=2)$ & Coast $(n=10)$ & Sea $(n=8)$ \\
\hline Temp $\left({ }^{\circ} \mathrm{C}\right)$ & $10.2(10.1-10.3)^{*}$ & $8.0(5.2-9.3)^{* * *}$ & $2.6(-0.8-4.5)$ \\
Sal & $0.2(0.2-0.2)^{*}$ & $17.0(7.0-23.6)^{* * *}$ & $26.3(22.5-27.9)$ \\
$\left.\mathrm{SPM}^{*} \mathrm{mg} \mathrm{L}^{-1}\right)$ & $111.8(82.1-141.6)^{*}$ & $7.0(1.0-20.6)^{* * *}$ & $0.4(0.04-1.0)$ \\
$\mathrm{NO}_{3}(\mu \mathrm{M})$ & $3.46(3.31-3.62)^{*}$ & $0.55(0.00-2.60)$ & $0.01(0.00-0.02)$ \\
$\mathrm{NH}_{4}(\mu \mathrm{M})$ & $0.21(0.20-0.22)$ & $0.34(0.02-1.48)^{* *}$ & $0.02(0.00-0.09)$ \\
$\mathrm{PO}_{4}(\mu \mathrm{M})$ & $0.02(0.02-0.02)^{*}$ & $0.19(0.06-0.36)^{* * *}$ & $0.47(0.33-0.60)$ \\
$\mathrm{Si}(\mu \mathrm{M})$ & $64.3(64.2-64.5)^{*}$ & $25.8(9.4-47.2)^{* * *}$ & $4.6(2.8-7.8)$ \\
$\mathrm{DOC}(\mu \mathrm{M})$ & $487.9(454.6-521.2)^{*}$ & $238.6(98.4-392.0)^{* *}$ & $86.7(68.3-103.4)$ \\
$\mathrm{DON}(\mu \mathrm{M})$ & $14.4(13.7-15.2)$ & $12.3(6.9-26.7)^{* * *}$ & $5.6(4.4-7.9)$ \\
$\mathrm{TDAA}(\mathrm{nM})$ & $532.7(527.4-537.9)$ & $456.2(317.3-551.6)^{* *}$ & $266.4(169.0-364.5)$ \\
$\mathrm{DOP}(\mu \mathrm{M})$ & $0.22(0.22-0.22)$ & $0.52(0.17-1.99)^{*}$ & $0.17(0.10-0.26)$ \\
$\mathrm{POC}(\mu \mathrm{M})$ & $62.4(52.0-72.8)^{*}$ & $19.0(6.9-26.7)^{* * *}$ & $5.5(2.5-7.1)$ \\
$\mathrm{PON}(\mu \mathrm{M})$ & $10.4(8.3-12.5)$ & $4.2(0.9-15.8)^{* *}$ & $0.8(0.2-1.1)$ \\
$\mathrm{POP}(\mu \mathrm{M})$ & $5.2(5.0-5.5)^{*}$ & $0.6(0.1-1.9)^{* * *}$ & $0.1(0.0-0.1)$ \\
$\mathrm{CDOM}\left(\mathrm{a}_{350} \mathrm{~m}^{-1}\right)$ & $5.9(5.6-6.3)^{*}$ & $3.3(1.1-5.6)^{* * *}$ & $0.4(0.1-0.8)$ \\
$\mathrm{Chl} a\left(\mathrm{mg} \mathrm{m}{ }^{-3}\right)$ & $3.1(3.0-3.2)^{*}$ & $1.2(0.2-2.7)$ & $0.7(0.1-2.2)$ \\
$\mathrm{BP}\left(\mu \mathrm{C} \mathrm{Cm}{ }^{-3} \mathrm{~d}^{-1}\right)$ & $136.7(106.6-166.9)^{*}$ & $115.9(91.6-145.0)$ & $44.0(6.9-131.0)$ \\
$\% \mathrm{PA} \mathrm{BP}$ & $99.4(99-99.7)^{*}$ & $38.2(0-81.7)$ & $41.1(22.8-97.0)$ \\
\hline
\end{tabular}

\subsection{Chemical and biological analyses}

Methods for chemical and biological analyses used to test environmental drivers of bacterial community structure are detailed elsewhere in this issue (i.e., Doxaran et al., 2012; Le Fouest et al., 2012; Matsuoka et al., 2012; Shen et al., 2012). Bacterial production (BP) was estimated from bacterial activity measures of ${ }^{3} \mathrm{H}$-leucine incorporation (Smith and Azam, 1992). Samples (1.5 mL in triplicate plus one killed control) were added to sterile microcentrifuge tubes, containing 10 to $20 \mathrm{nM}\left[4,5-{ }^{3} \mathrm{H}\right]$-leucine (specific activity $139 \mathrm{Ci} \mathrm{mmole}^{-1}$ ) (Ortega-Retuerta et al., 2012b). Separate sample aliquots were gravity filtered through $3 \mu \mathrm{m}$-pore size polycarbonate filters; free-living bacterial production was measured in the filtrate. This was subtracted from BP determined in whole seawater to calculate the percentage of particle-attached BP $(\%)$.

\subsection{Bacterial community structure by capillary electrophoresis-single-strand conformation polymorphism (CE-SSCP) fingerprinting}

Samples for bacterial community structure were sequentially filtered through $3 \mu \mathrm{m}$-pore size polycarbonate filters $(47 \mathrm{~mm}$ diameter) (particle-attached fraction) and $0.2 \mu \mathrm{m}$-pore size Sterivex filters (free-living fraction) using a peristaltic pump under low pressure. The fraction larger than $3 \mu \mathrm{m}$ was confirmed to contain only bacteria attached to particles by visual examination of DAPI-stained samples using epifluorescence microscopy (data not shown). One to two liters of water were filtered depending on suspended solid concentration to avoid filter clogging. Samples were subsequently stored at $-80^{\circ} \mathrm{C}$ until processing at the home laboratory. DNA and RNA co-extraction, polymerase chain reaction (PCR) and reverse transcriptase (RT)-PCR were performed as previously described (Ghiglione et al., 2009). Both DNA and cDNA were used as a template for PCR amplification of the variable V3 region of the $16 \mathrm{~S}$ rRNA gene with primers w49F (5'-ACG GTC CAG ACT CCT ACG GG-3') fluorescently $5^{\prime}$-labeled with phosphoramidite (TET, Eurogentec) and w34R ( $5^{\prime}$-TTA CCG CGG CTG CTG GCA C-3') according to Ghiglione et al. (2005). CE-SSCP and analysis of the electroferograms were performed using the 310 Genetic Analyzer and GeneScan analysis software (Applied Biosystems), as described previously (Ghiglione et al., 2008).

\subsection{Bacterial diversity, community structure and composition by pyrosequencing}

Bacterial tag-encoded FLX amplicon pyrosequencing (bTEFAP) was performed as described previously using Gray28F (5'TTTGATCNTGGCTCAG) and Gray519r 


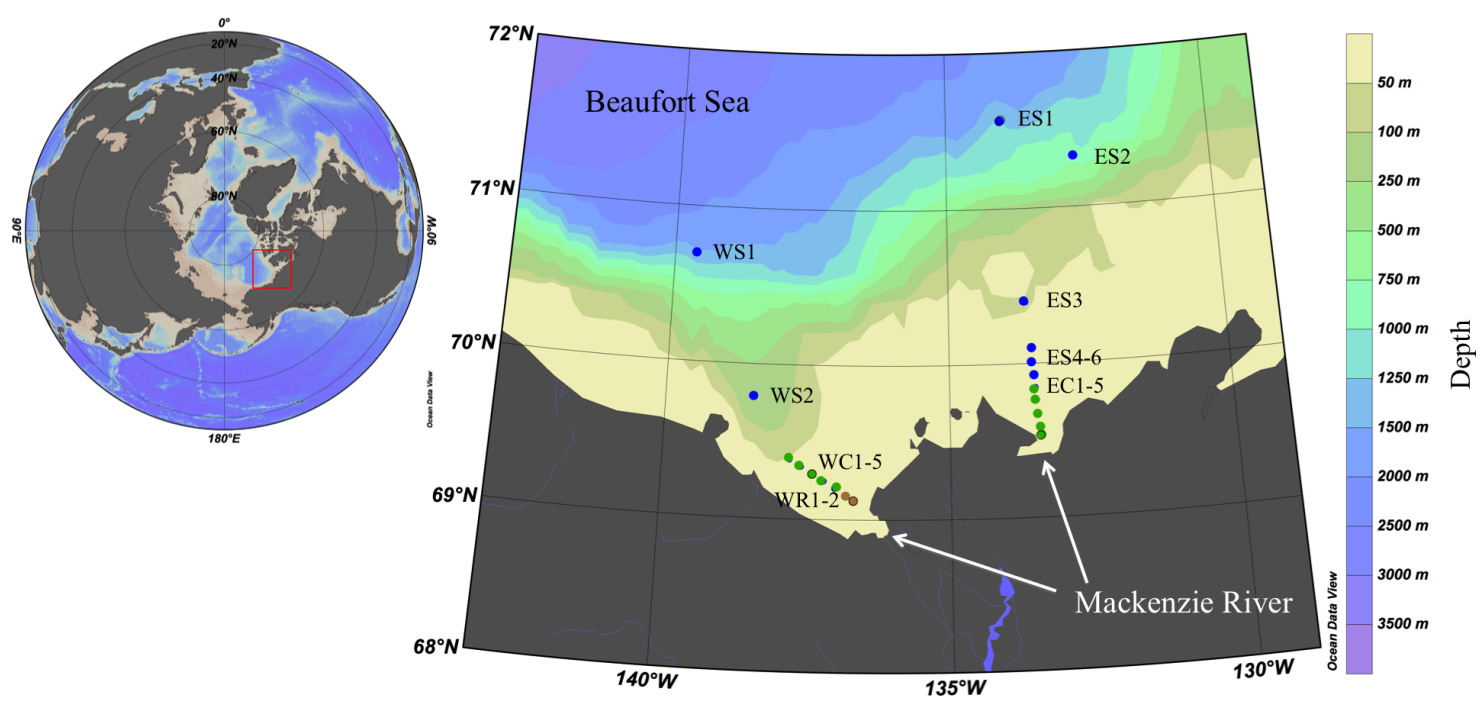

Fig. 1. Study area and station locations. Blue dots: stations considered as "open sea". Green dots: stations considered as "coast". Brown dots: stations considered as "river".

(5'GTNTTACNGCGGCKGCTG) (Sun et al., 2011) amplifying $400 \mathrm{bp}$ of the V6 region of the 16S rRNA gene. Initial generation of the sequencing library was accomplished by a one-step PCR with a total of 30 cycles using the HotStarTaq Plus Master Mix Kit (Qiagen, Valencia, CA) and amplicons originating and extending from the Gray $28 \mathrm{~F}$ primer for bacterial diversity. Tag-encoded FLX amplicon pyrosequencing analyses were completed using the Roche 454 FLX instrument with Titanium reagents, and procedures were performed at the Research and Testing Laboratory (Lubbock, TX) based upon RTL protocols.

Sequences were processed and analyzed using the Qiime software (Caporaso et al., 2010). Briefly, samples were denoised using the AmpliconNoise program and checked for chimeras using Perseus (Quince et al., 2011). The resulting clean sequences were clustered using operational taxonomic units (OTUs) at a $97 \%$ sequence identity level using the UCLUST algorithm (Edgar, 2010). A representative sequence from each OTU was classified using the Ribosomal Database Project (RDP) classifier (Wang et al., 2007) using the Greengenes training set. Taxonomic identification of the sequence reads (tags) followed the approach by Sogin et al. (2006) and Huse et al. (2010). To normalize the number of tags sequenced between samples, tags were randomly resampled to the sample with the fewest tags (2826 tags) using Daisychopper v. 0.6 (Gilbert et al., 2009). This step was performed on operational taxonomic unit (OTU) files clustered at a distance of 0.03 (Ghiglione and Murray, 2012).

\subsection{Diversity estimators and cluster analysis}

All OTU and diversity analyses were performed on the randomly re-sampled datasets. We used SPADE (Species Prediction and Diversity Estimation; http://chao.stat.nthu.edu) to calculate the non-parametric species richness estimator Chao1. PAST (PAleontological STatistics v 1.19; http://folk.uio.no/ohammer/past/) was used to generate rarefaction curves. Both Simpson and Shannon diversity indexes (that take into account both richness and evenness) were calculated using PRIMER 6 software (PRIMER-E, UK). Bacterial community structures, either as number and area of the peaks in the CE-SSCP profiles or presence and abundance of OTU in the pyrosequencing data, were compared using ordination of Bray-Curtis similarities and used to build dendrograms by the unweighted-pair group method with arithmetic averages (UPGMA). A similarity profile test (SIMPROF, PRIMER 6) was performed on a null hypothesis that a specific sub-cluster can be recreated by permuting the entry species and samples. The significant branch (SIMPROF, $p<0.05$ ) was used as a prerequisite for defining bacterial clusters. One-way analysis of similarity (ANOSIM, PRIMER 6) was performed on the same distance matrix to test the null hypothesis that there was no difference between bacterial communities of different clusters.

\subsection{Direct multivariate analysis}

To investigate the relationships between bacterial community structure and environmental parameters, we used a directgradient approach, i.e., a canonical correspondence analysis (CCA) using the software package CANOCO, version 4.5 for Windows, as previously described (Berdjeb et al., 2011). Spearman rank pairwise correlations between the environmental variables helped to determine their significance. To statistically evaluate the significance of the canonical axes, we used a Monte Carlo permutation full model test with 199 unrestricted permutations. Significant variables were chosen using a forward-selection procedure and 999 permutations, 


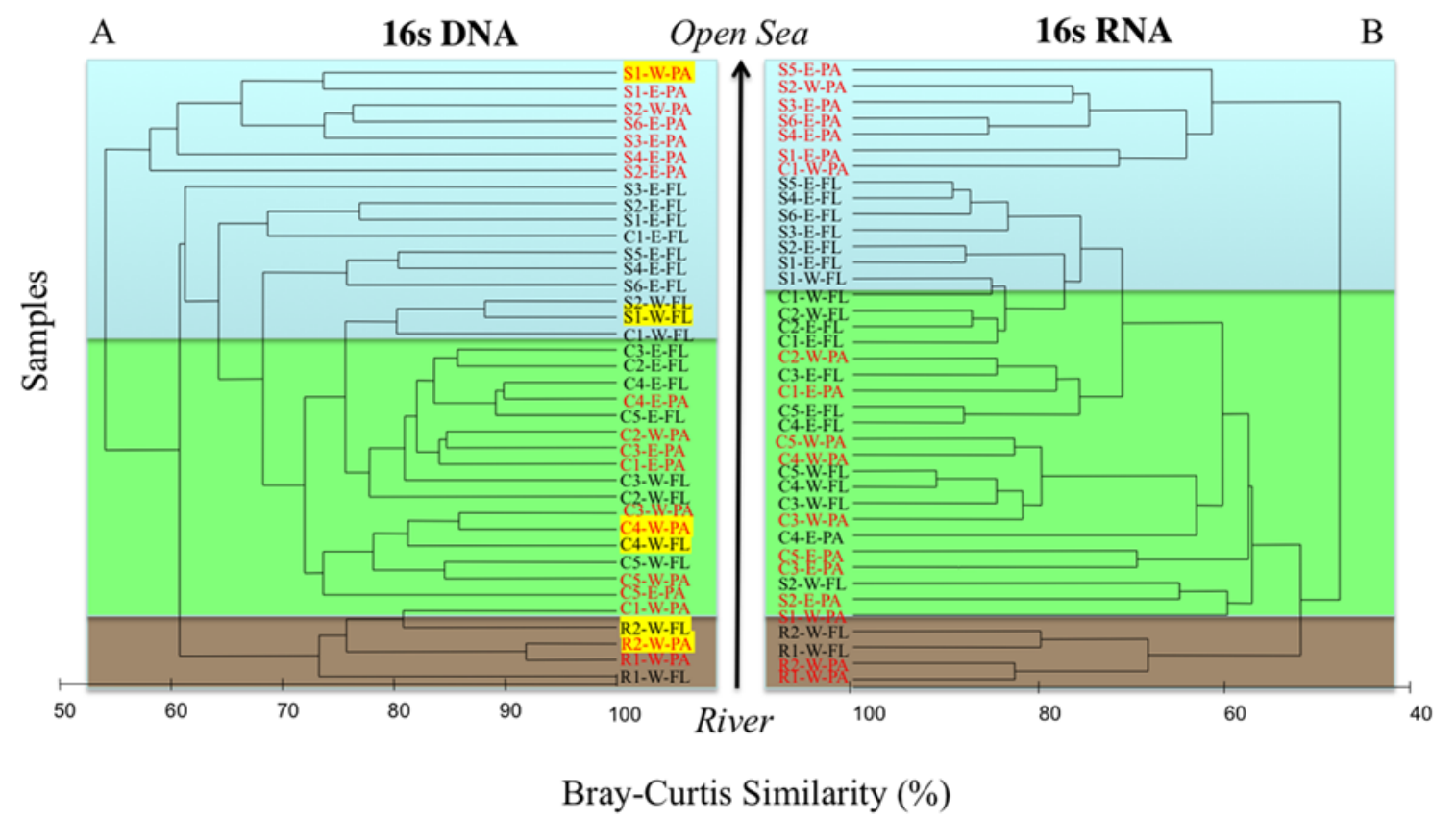

Fig. 2. Unweighted-pair group method with arithmetic mean (UPGMA) dendrograms based on Bray-Curtis similarities of DNA-based (A) and RNA-based (B) CE-SSCP fingerprints of particle-attached (PA, red letters) and free-living (FL, black letters) bacteria. Blue rectangles: stations considered as "open sea" (S). Green rectangles: stations considered as "coast" (C). Brown rectangles: stations considered as "river" (R). W: western transect. E: eastern transect. Samples selected for tag pyrosequencing are highlighted in yellow.

and explanatory variables were added until further addition of variables failed to contribute significantly $(p<0.05)$ to a substantial improvement to the model's explanatory power.

\section{Results}

\subsection{Study area characterization}

According to physical and chemical water properties (Table 1), we defined three zones relative to the proximity of the river in both eastern and western transects in the Mackenzie River. Stations with salinity 0 were named "river" (R). These stations were characterized, aside from fresh water, by higher temperature (average $10.2^{\circ} \mathrm{C}$ ) and suspended particulate matter (SPM; average $111.8 \mathrm{mg} \mathrm{L}^{-1}$ ). Coastal stations and open sea stations were separated according to physical and chemical features: stations considered "coastal" (C) were characterized by Mackenzie River water influence, showing salinity below 24 , surface temperature higher than $4.5^{\circ} \mathrm{C}$ and SPM concentrations higher than $1 \mathrm{mg} \mathrm{L}^{-1}$. "Open sea" (S) stations showed salinity higher than 26 except for station WS1, which was influenced by ice melt waters, temperatures lower than $4.5^{\circ} \mathrm{C}$ and SPM below $1 \mathrm{mg} \mathrm{L}^{-1}$. The western river transect showed a higher influence by river waters than the eastern transect (i.e., lower salinity and higher SPM concentration, data not shown).

Bacterial production was significantly higher in the Mackenzie River mouth and decreased offshore (Table 1).
The proportion of bacterial production due to particleattached (PA) bacteria was not different in marine and coastal stations (average 41 and $38 \%$, respectively, Table 1). In contrast, most of the bacterial production was performed by PA bacteria in riverine stations (average $99 \%$ of the total bacterial production).

\subsection{Changes in bacterial community structure measured by CE-SSCP}

Overall, we observed significant spatial differences in bacterial community structure in both western and eastern transects from the Mackenzie River to the Beaufort Sea (Table 2, Fig. 2). The highest differences were found between river and open sea samples (ANOSIM $R^{2}=0.63, p<0.001$ ), whereas no clear difference was observed between samples from the eastern (Kugmallit Bay) and western (Shallow Bay) transects (Table 2). Coastal communities were more similar to open sea than river samples (ANOSIM $R^{2}=0.33, p<0.001$ and $R^{2}=0.36, p<0.001$, respectively). Hierarchical clustering based on Bray-Curtis similarity between CE-SSCP profiles showed a clear organization according to the distance to the coast in each river, coastal and open sea clusters (Fig. 2). Consequently, samples from river, coast and open sea were treated separately for further detailed comparisons.

In open sea samples, we observed significant differences between PA and FL communities (Table 2) and, indeed, PA 
(A)

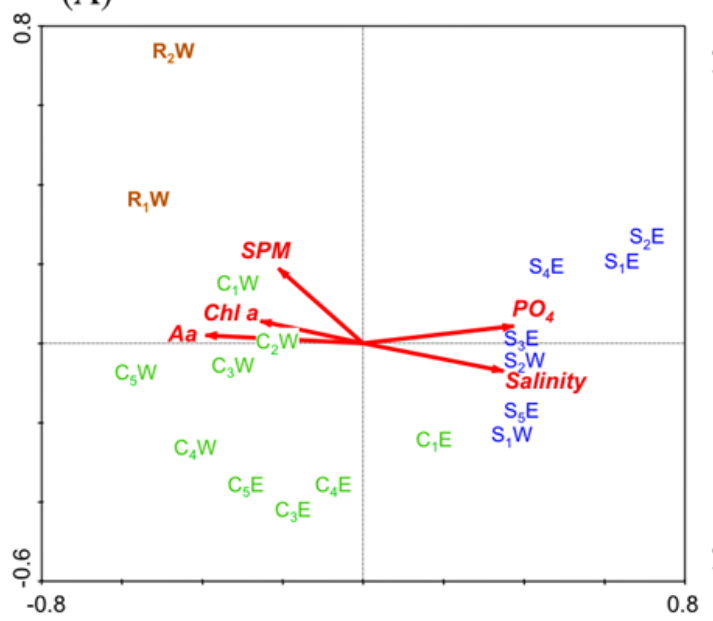

(B)

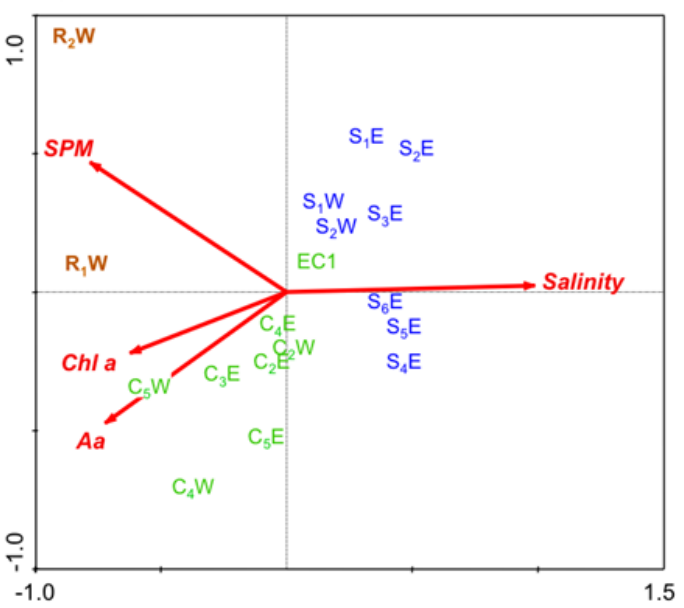

Fig. 3. Canonical correspondence analysis of bacterioplankton community structure from particle-attached (PA, A) and free-living (FL, B) samples using environmental variables. The length of the arrow represents degree of correlation with presented axis. SPM: suspended particulate matter. Chl $a$ : chlorophyll $a$ concentration. Aa: amino acid concentration. $\mathrm{PO}_{4}$ : phosphate concentration. Brown letters: river samples. Green letters: coast samples. Blue letters: open sea samples

Table 2. Results of ANOSIM analyses to test significant differences in community structure between DNA (indicative of all present OTUs) and RNA (indicative of active OTUs), between transects (western and eastern) and between locations (river, coast and sea). From those groups showing significant differences in community structure, we then tested the different groups separately for differences between particle-attached (PA) and free-living (FL) community structure and between total and active community structure. $R^{2}=$ explained variance. $p$ level $=$ level of significance. $\mathrm{NS}=$ non-significant.

\begin{tabular}{llrr}
\hline Sample chosen & Factor & $R^{2}$ & $p$ level \\
\hline All & DNA-RNA & 0.09 & 0.003 \\
All & Transect & 0.08 & 0.004 \\
All & Location & 0.39 & 0.001 \\
\hline Sea & PA-FL & 0.80 & 0.001 \\
Coastal & PA-FL & 0.12 & 0.005 \\
River & PA-FL & NS & NS \\
\hline Sea & DNA-RNA & 0.01 & NS \\
Coastal & DNA-RNA & 0.20 & 0.001 \\
River & DNA-RNA & 0.71 & 0.029 \\
\hline
\end{tabular}

sea samples formed a single cluster, with Bray-Curtis similarities to the rest of samples lower than $60 \%$ in DNA-based profiles and lower than $50 \%$ in RNA-based profiles (Fig. 2). The differences were also significant for coastal samples $(p<0.05)$, although the percentage of explained variance was low $\left(R^{2}=0.12\right)$. No significant differences were found between PA and FL communities in the river samples.

When comparing DNA- and RNA-based fingerprints, significant differences were obtained for riverine or coastal sam- ples, but not for open sea samples (Table 2). The highest difference was found between DNA- and RNA-based profiles from river samples (ANOSIM $R^{2}=0.7, p<0.05$ ), as depicted in Supplement Fig. 1.

\subsection{Environmental drivers of bacterial community structure}

A strong Spearman's rank pairwise correlation was found between CDOM, DOC, Si and salinity. In our dataset, the correlation coefficients were $-0.96,-0.97$ and -0.95 between salinity and CDOM, DOC and Si respectively ( $p<0.01, n=$ $20)$. Therefore, salinity was used as a proxy of these parameters for further direct multivariate statistical analysis. We performed canonical correspondence analysis (CCA) in order to explore which environmental factors drive the spatial distribution of PA and FL bacterial communities. As no significant differences were observed between DNA and RNA-based fingerprints (Table 2), we used only DNA-based profiles for CCAs. Similar results were found for the RNA fraction.

In both PA and FL DNA samples, the cumulative percentage of variance of the species-environment relationship indicates that the first and second canonical axis explained $47.0 \%$ and $22.5 \%$ of this variance, respectively, for PA and $44.1 \%$ and $29.5 \%$ of this variance, respectively, for FL (Table 3). Consequent axes accounted for less than $16.5 \%$ of the variance each and, thus, were no longer considered. In both PA and FL DNA-based CCA, the first canonical axis was highly positively correlated with salinity (and phosphate in the case of PA fraction, but not in the FL fraction) and negatively correlated with the concentration of chlorophyll $a$, amino acids and SPM (Fig. 3). The concomitant effect of these parameters explained $59 \%$ and $48 \%$ (ratio between the 


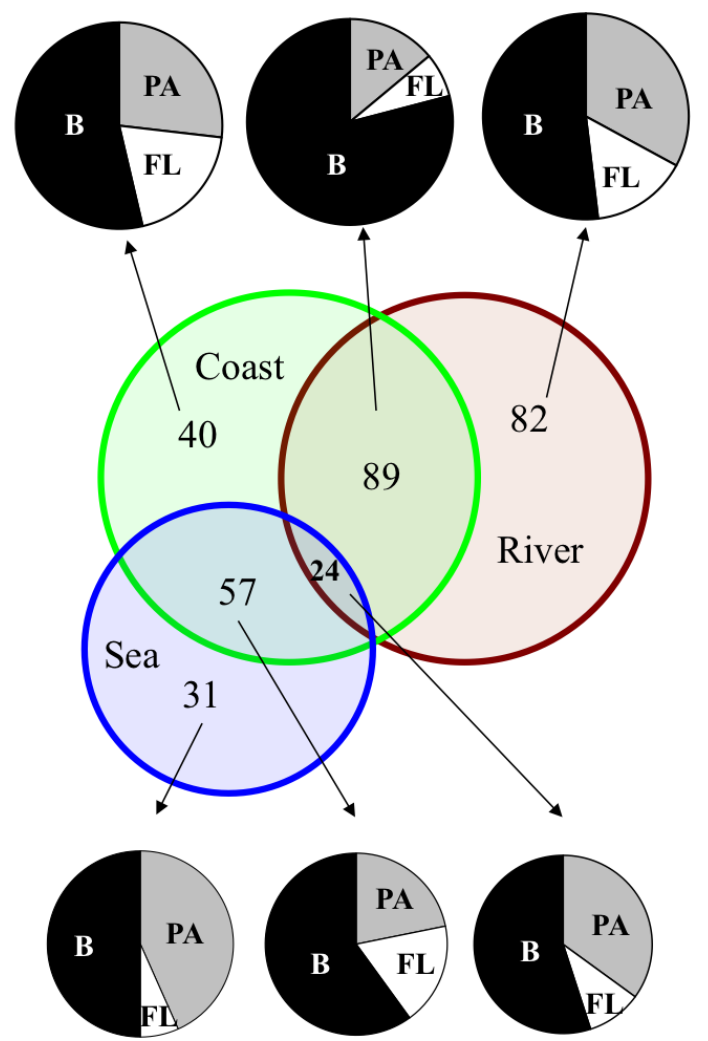

Fig. 4. OTU distribution between open sea (blue circle), coast (green circle) and river (brown circle) (areas are proportional to the number of OTUs). Relative abundance of all exclusive and shared OTUs in the particle-attached fraction (PA), in the free-living fraction (FL) or in both fractions (B) is also shown.

sum of all canonical eigenvalues and the sum of all eigenvalues) of the changes in bacterial community structure found in the PA and FL fractions, respectively (Table 3).

\subsection{Bacterial diversity by tag pyrosequencing}

According to CE-SSCP results (Fig. 2), we selected six samples in the western transect representative of the river $\left(\mathrm{R}_{2} \mathrm{~W}\right)$, coast $\left(\mathrm{C}_{4} \mathrm{~W}\right)$ and open sea $\left(\mathrm{S}_{1} \mathrm{~W}\right)$ for pyrosequencing-based analysis of the PA and FL fractions. After removing lowquality tags, a total of 60544 reads were obtained for the six samples analyzed, with a minimum of 2826 tags per sample. All the further analyses were based on the OTU table following re-sampling to the lowest abundant tag (2826) and clustering at a distance of 0.03 . Out of the total 323 OTUs found in our samples, 195 OTUs were found in the river, 210 OTUs in the coast and 112 OTUs in the open sea (Fig. 4). All richness and diversity indexes showed higher values at the coastal and river stations than at the open sea station (Table 4, Supplement Fig. 2).

We compared the presence vs. absence of OTUs merging both fractions in sea, coast and river samples (Fig. 4). 82 OTUs ( $24.3 \%$ of total OTUs) were exclusive to the river,

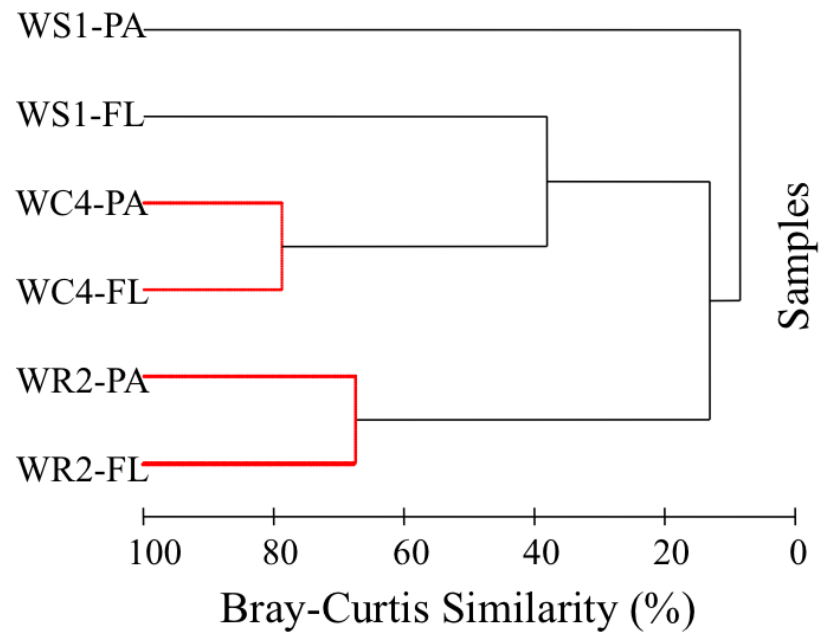

Fig. 5. UPGMA dendrograms based on Bray-Curtis similarities of DNA 454-tag sequences. PA: particle-attached bacteria; FL: freeliving bacteria; S: sea; C: coast; R: river. Single clusters with nonsignificant differences between samples are marked in red.

43 OTUs ( $12.8 \%$ ) exclusive to the coast and 33 OTUs exclusive to the sea sample $(9.8 \%)$. Only 24 OTUs $(7.1 \%)$ were shared at all three zones, and there was a higher degree of OTUs sharing between coast and river $(26.4 \%)$ than between sea and coast (17.2\%) (Fig. 4).

In all the three samples, the diversity of PA was always higher than for FL bacteria (Table 4). Sixty percent of OTUs shared between sea and coast samples and $78 \%$ of OTUs shared between coast and river samples were found in both PA and FL fractions. Conversely, a large percentage of OTUs that were exclusive to either sea or river samples were also exclusive to the PA fraction. In other words, $43.3 \%$ of OTUs exclusive to the sea sample and $32.9 \%$ of OTUs exclusive to the river sample were also exclusive to the PA fraction (Fig. 4).

Hierarchical clustering of tag occurrence profiles showed similar clustering to CE-SSCP profiles, albeit with fewer samples (Fig. 5). Bacterial community structure was different among coast, river and sea samples. Looking at specific areas, PA bacteria were very different than FL bacteria in sea samples (Fig. 5), with only $15.7 \%$ of similarity whilst there were much fewer differences between PA and FL communities in the coast and river samples (78.8 and $67.5 \%$ similarity, respectively). Differences between PA and FL fractions in open sea were also visible upon closer inspection of their respective taxonomic compositions (Fig. 6). At the class level, the PA open sea sample was dominated by the classes Opitutae (31\% of all reads), Flavobacteria (29\%) and Gammaproteobacteria (19\%). The free-living fraction of the open sea samples was dominated by Alphaproteobacteria (54\% of all reads), followed by Actinobacteria and Flavobacteria (12\% and $12 \%$, respectively). In the coast sample, in both PA and FL fractions, the most abundant 
Table 3. Results of canonical correspondence analyses (CCAs). PA: particle-attached. FL: free-living.

\begin{tabular}{|c|c|c|c|c|c|}
\hline DNA PA & & & & & \\
\hline Axes & 1 & 2 & 3 & 4 & \\
\hline Eigenvalues & 0.178 & 0.085 & 0.049 & 0.035 & \\
\hline Species-environment correlations & 0.937 & 0.896 & 0.829 & 0.858 & \\
\hline $\begin{array}{l}\text { Cumulative percentage variance } \\
\text { of species data }\end{array}$ & 27.8 & 41.2 & 48.9 & 54.4 & \\
\hline $\begin{array}{l}\text { Cumulative percentage variance } \\
\text { of species-environment relation }\end{array}$ & 47.0 & 69.5 & 82.5 & 91.8 & \\
\hline Sum of all eigenvalues & & & & & 0.638 \\
\hline Sum of all canonical eigenvalues & & & & & 0.378 \\
\hline \multicolumn{6}{|l|}{ DNA FL } \\
\hline Axes & 1 & 2 & 3 & 4 & \\
\hline Eigenvalues & 0.088 & 0.059 & 0.033 & 0.020 & \\
\hline Species-environment correlations & 0.963 & 0.899 & 0.891 & 0.718 & \\
\hline $\begin{array}{l}\text { Cumulative percentage variance } \\
\text { of species data }\end{array}$ & 21.1 & 35.3 & 43.2 & 48.0 & \\
\hline $\begin{array}{l}\text { Cumulative percentage variance } \\
\text { of species-environment relation }\end{array}$ & 44.1 & 73.6 & 90.1 & 100.0 & \\
\hline Sum of all eigenvalues & & & & & 0.414 \\
\hline Sum of all canonical eigenvalues & & & & & 0.199 \\
\hline
\end{tabular}

class was Alphaproteobacteria (34\%), followed by Betaproteobacteria (14\% and $19 \%$ in PA and FL, respectively) and Actinobacteria (13\% and $11 \%$ in PA and FL, respectively). Finally, the river sample was dominated by Betaproteobacteria (26\% and $31 \%$ in PA and FL samples, respectively). Actinobacteria were more abundant in the PA fraction $(24 \%)$ than in the FL one $(11 \%)$, while Alphaproteobacteria relative abundance was similar in the two fractions $(22 \%$ and $25 \%$, Fig. 6). Some OTUs that were exclusive to the river included members of Nostocales (Cyanobacteria), Caulobacterales (Alphaproteobacteria) or different Betaproteobacteria groups (e.g., Burkholderiales, Methylophilales), while some OTUs exclusive to the sea included OTUs belonging to Flavobacteriales (Flavobacteria) and Oceanospirillales Gammaproteobacteria).

\section{Discussion}

The MALINA Arctic campaign sampled the Mackenzie Delta-Beaufort shelf area during summer in 2009 revealing an ecosystem characterized by its oligotrophy (i.e., low primary production, Ortega-Retuerta et al., 2012b; dissolved amino acids, and labile organic matter, Shen et al., 2012). This was partially sustained by Mackenzie River inputs that structured a complex gradient of suspended particles with mineral to organic content (Doxaran et al., 2012) as well as a shelf-basin gradient of sinking particles and sediment flux (Forest et al., 2012). Under these conditions, we found that almost half of the bacterial production in the open sea and
$99 \%$ in the river was due to PA bacteria, which is consistent with previous measurements in the Mackenzie River and Beaufort Sea (Galand et al., 2008; Vallieres et al., 2008; Garneau et al., 2009). The investigation of bacterial community structure associated with those particles is of interest to gain knowledge about particle remineralization pathways and nutrient cycling in the system. This will serve as a basis to predict further changes in bacterial communities in the area, and hence on biogeochemical processes, in a scenario of increased particle loads to the system via river discharge (Peterson et al., 2002) and increased primary production (Arrigo and van Dijken, 2011). To our knowledge, this is the first study using CE-SSCP and tag sequencing to differentiate PA and FL bacteria in the Arctic Ocean. The combination of these techniques has proven robust for ecological studies on aquatic microbial diversity (Ghiglione and Murray, 2012).

\subsection{Spatial variability of bacterial community structure}

The principal factor determining bacterial community structure at the surface in our system was the sample location (river, coast, open sea). Previous studies have documented a transition from freshwater to marine communities (Riemann and Middelboe, 2002; Troussellier et al., 2002; Campbell and Kirchman, 2012). For instance, bacterial community composition in river and sea samples (if we merged PA and FL fractions together) was similar to the one reported by Galand et al. (2008). We report a transition from a community dominated by members frequently found to dominate in fresh waters, such as Actinobacteria (Holmfeldt et al., 2009) or 


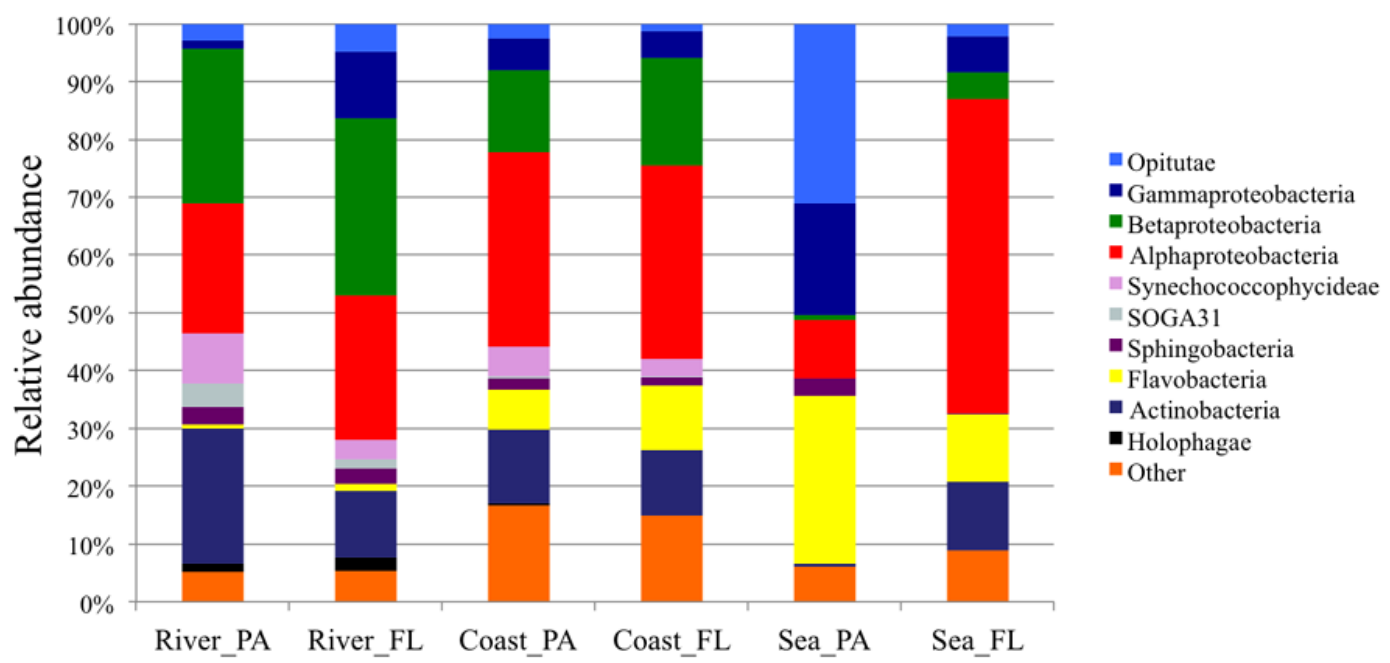

Fig. 6. Cumulative bar charts comparing the relative class abundances in particle-attached (PA) and free-living (FL) selected samples.

Table 4. Number of OTUs at 0.03 level of clustering, and Chao1, Shannon and Simpson diversity indexes after 454-tag pyrosequencing for the selected samples. PA: particle-attached. FL: free-living.

\begin{tabular}{llrrrrr}
\hline Sample & Fraction & N reads & N OTUs & Chao1 & Shannon & Simpson \\
\hline Sea & PA & 2826 & 105 & $137.5 \pm 17.2$ & 2.97 & 0.1859 \\
& FL & 2826 & 80 & $103.0 \pm 12.5$ & 2.67 & 0.1798 \\
Coast & PA & 2826 & 179 & $232.1 \pm 18.8$ & 3.82 & 0.2559 \\
& FL & 2826 & 162 & $240.1 \pm 26.6$ & 3.62 & 0.2302 \\
River & PA & 2826 & 166 & $192.5 \pm 10.9$ & 3.49 & 0.1975 \\
& FL & 2826 & 144 & $179.9 \pm 14.6$ & 3.21 & 0.1718 \\
\hline
\end{tabular}

Betaproteobacteria (Garneau et al., 2006), to a typical marine bacterial community dominated by Alphaproteobacteria (Fig. 6). The low degree of overlap between river and sea groups (Fig. 4) indicates the low dispersal potential, or low viability in marine waters of riverine bacteria. Even when the Mackenzie River plume extended more than $200 \mathrm{~km}$ offshore, studies performed during the same campaign reported that SPM was limited to close to the river mouth (Doxaran et al., 2012). CCAs confirmed a spatial structuring of bacterial community driven by salinity (proxy of DOC and CDOM), chlorophyll $a$, amino acids and SPM. We have previously shown that bacterial abundance and activity (production and respiration) was controlled by the availability of labile organic matter, with DOC, amino acids and primary production as proxies (Ortega-Retuerta et al., 2012b). This supports that these factors (DOC, amino acids, labile organic matter) control both bacterioplankton activity and community structure in this region, an important fact given that the community structure affects its activity (e.g., Obernosterer et al., 2010). As the station location was the main factor determining bacterial communities, both PA and FL seemed to be driven by similar environmental variables. The influence of river inputs and temperature on bacterial community structure was also shown in a previous study in the Arctic (Kellogg and Dem- ing, 2009) and in a global comparison of bacterial diversity including Arctic samples (Ghiglione et al., 2012).

\subsection{Role of particles on bacterial community structure}

Significant differences between PA and FL bacteria were, unexpectedly, only observed in open sea samples but not in the river nor in the coastal samples, even when particle concentration was much higher in the river and coast (Table 1). This result contrasts to previous observations in the Mackenzie River-Beaufort Sea system, where highest differences in PA vs. FL fractions were found in the Mackenzie River estuary (Garneau et al., 2009), but is similar to the results of Kellogg and Deming (2009) from the Laptev Sea along the Arctic shelf as influenced by the Lena River, where no differences were observed in PA $(>3 \mu \mathrm{m})$ vs. FL $(<3 \mu \mathrm{m})$ bacterial communities. We suggest that particle quality, rather than their quantity, would play a major role structuring bacterial communities. The relationship between particulate organic carbon (POC) and SPM may provide information about the nature of the particles, from mineral to organic (Wozniak et al., 2010). During the MALINA cruise, particles in the river and coast samples showed POC:SPM ratios of $2.2 \%$ (i.e., mineral-rich particles), while particles 
in the open sea showed POC:SPM ratios of $12.2 \%$ (i.e., organic-rich) (Doxaran et al., 2012). Therefore, the particulate organic substrates were likely influencing the bacterial communities growing on them, similar to the results of Garneau et al. (2009) that showed differences between PA and FL bacteria at locations with highest POM content.

These results were reinforced by tag pyrosequencing of selected samples. The higher bacteria diversity in PA than in FL samples (Table 4) and the presence of more unique OTUs in the PA fraction than in the FL one (Fig. 4) indicates the existence of particle specialists. On the other hand, within the OTUs that were shared between river, coast and open sea samples (i.e., cosmopolitan OTUs), there was a higher proportion of OTUs found on both PA and FL fractions than within OTUs exclusive to a certain location (river, coast or open sea). This suggests that cosmopolitan OTUs were also generalists in their lifestyle. Conversely, within OTUs exclusive to river or marine locations, we could observe more specialists, mainly to particles (Fig. 4). A closer look into community composition in those samples suggests different underlying mechanisms: in the open sea sample, groups found to prevail at the PA fraction suggest adaptation to PA lifestyles. For instance, Flavobacteria, highly represented in our PA sea sample (Fig. 6), are specialized in adhesion to particles, as shown in a recent study using metaproteomics (Williams et al., 2012). Also, members of Verrucomicrobia (Phylum that contains the class Opitutae), dominant in our PA open sea samples, are known to be active polysaccharide degraders (Martinez-Garcia et al., 2012). Conversely, some of the groups found in PA fraction from the river and the coast samples were bacteria previously observed in sediments or in land, such as the groups Rhodocyclales and Methylophilales, involved in denitrification processes (Ginige et al., 2004; Ishii et al., 2009). These groups will likely not spread far offshore, and may be partially the cause for the higher presence of non-active OTUs in river samples. This may explain the significant differences between DNA- and RNA-based fingerprints in surface waters of the river (Table 2, Supplement Fig. 1). Previous studies have also found higher diversity in the PA fraction, such as in deep samples of the Puerto Rico trench, using clone libraries (Eloe et al., 2011), in the upper euphotic layer of the Mediterranean Sea using 454-tag pyrosequencing (Crespo et al., 2013) or in suboxic zones of the Black Sea using 454-tag pyrosequencing (Fuchsman et al., 2012). However, this is in contrast with other studies in marine and fresh waters (Ghiglione et al., 2007) including the Arctic (Kellog and Deming, 2009) where a higher diversity in the FL fraction has been observed. Additional work is needed to establish which conditions favor bacterial specialization, or where generalists will prevail.

\section{Conclusions and implications}

In this study we have applied for the first time a combination of fingerprinting and 454-tag pyrosequencing to investigate patterns of PA and FL bacterial community structure in an Arctic system. Despite the outcome that location (river, coast, open sea) and their associated differences in salinity, DOC, SPM or amino acids were the main structuring factor was expected, the reported spatial patterns of bacterial community structure may give us hints about potential biogeochemical processes. For instance, we noted the presence of Nostocales in the river sample. This group has been previously observed in the same location and recognized as potential $\mathrm{N}_{2}$ fixers (Blais et al., 2012). $\mathrm{N}$ fixation has been observed in the Mackenzie shelf (Blais et al., 2012) and may play a crucial role in $\mathrm{N}$ cycling by partially alleviating strong $\mathrm{N}$ limitation in the area (Tremblay and Gagnon, 2009; Ortega-Retuerta et al., 2012a). Other groups of biogeochemical relevance are aerobic anoxygenic phototrophic bacteria (AAPs), whose contribution is higher in the Mackenzie River delta and who belong mainly to the phylum Betaproteobacteria (Boeuf et al., 2013), which also dominated in our river sample.

The distinction between PA and FL communities allowed us to observe a high degree of specialization in Beaufort Sea communities where particles are likely organic. Conversely, we saw a high degree of overlap between PA and FL communities in coast and Mackenzie River samples where particles have a higher mineral content. These contrasting patterns also suggest different metabolisms within particles, which will likely affect the fate of these particles in the water column (remineralization and sedimentation processes). Previous studies in the area have reported that bacteria attenuate marine particle fluxes via enzymatic hydrolysis (Kellogg et al., 2011) and contribute to the remineralization of sinking particles (Forest et al., 2012) while others have reported a low degree of bacterial remineralization in phytoplanktonderived particulate matter (Rontani et al., 2012). Further work is needed to link particle composition, as a proxy for substrate quality, to bacterial metabolism and diversity.

\section{Supplementary material related to this article is available online at: http://www.biogeosciences.net/10/ 2747/2013/bg-10-2747-2013-supplement.pdf.}

Acknowledgements. We thank the crew of Canadian icebreaker Amundsen for their assistance in the field. We are grateful to many MALINA participants for sharing physico-chemical data: Y. Gratton for CTD data, P. Raimbault and J. E. Tremblay for nutrient data, D. Doxaran, J. Ehn and S. Bélanger for SPM, POC and Chl $a$ data, A. Matsuoka for CDOM data, Y. Shen and R. Benner for DOC and TDAA data. This work was funded by the French National 
Research Agency, under the grant no. ANR-BLAN08-1_310980 to the MALINA project, the LEFE-CYBER and CNES-TOSCA programs, and the European Space Agency. W. H. J was supported by a University of West Florida faculty Scholarly and Creative Activity award.

Edited by: W. Li

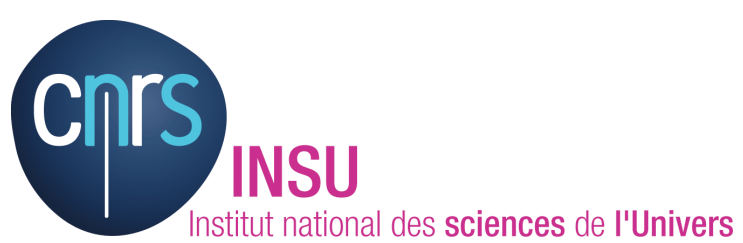

The publication of this article is financed by CNRS-INSU.

\section{References}

Acinas, S. G., Rodriguez-Valera, F., and Pedrós-Alió, C.: Spatial and temporal variation in marine bacterioplankton diversity as shown by RFLP fingerprinting of PCR amplified $16 \mathrm{~S}$ rDNA, FEMS Microbiol. Ecol., 24, 27-40, doi:10.1111/j.15746941.1997.tb00420.x, 1997.

Acinas, S. G., Antón, J., and Rodríguez-Valera, F.: Diversity of freeliving and attached bacteria in offshore Western Mediterranean waters as depicted by analysis of genes encoding 16S rRNA, Appl. Environ. Microbiol., 65, 514-522, 1999.

Arrigo, K. R. and van Dijken, G. L.: Annual cycles of sea ice and phytoplankton in Cape Bathurst polynya, southeastern Beaufort Sea, Canadian Arctic, Geophys. Res. Lett., 31, L08304, doi:10.1029/2003g1018978, 2004.

Arrigo, K. R. and van Dijken, G. L.: Secular trends in Arctic Ocean net primary production, J. Geophys. Res.-Oceans, 116, C09011, doi:10.1029/2011jc007151, 2011.

Azam, F. and Malfatti, F.: Microbial structuring of marine ecosystems, Nat. Rev. Micro., 5, 782-791, 2007.

Azam, F., Smith, D. C., Steward, G. F., and Hagstrom, A.: Bacteriaorganic matter coupling and its significance for oceanic carbon cycling Microb. Ecol., 28, 167-179, doi:10.1007/bf00166806, 1994.

Berdjeb, L., Ghiglione, J.-F., and Jacquet, S.: Bottom-up versus topdown control of hypo- and epilimnion Ffree-living bacterial community structures in two neighboring freshwater lakes, Appl. Environ. Microbiol., 77, 3591-3599, doi:10.1128/aem.02739-10, 2011.

Blais, M., Tremblay, J.-r., Jungblut, A. D., Gagnon, J., Martin, J., Thaler, M., and Lovejoy, C.: Nitrogen fixation and identification of potential diazotrophs in the Canadian Arctic, Global Biogeochem. Cy., 26, GB3022, doi:10.1029/2011gb004096, 2012.

Boeuf, D., Cottrell, M. T., Kirchman, D. L., Lebaron, P., and Jeanthon, C.: Summer community structure of aerobic anoxygenic phototrophic bacteria in the western Arctic Ocean, FEMS Microbiol. Ecol., in press, 2013.

Campbell, B. J. and Kirchman, D. L.: Bacterial diversity, community structure and potential growth rates along an estuarine salinity gradient, ISME J., 7, 10-220, 2012.
Caporaso, J. G., Bittinger, K., Bushman, F. D., DeSantis, T. Z., Andersen, G. L., and Knight, R.: PyNAST: a flexible tool for aligning sequences to a template alignment, Bioinformatics, 26, 266267, doi:10.1093/bioinformatics/btp636, 2010.

Corell, R. W. and Cleveland, C.: Arctic Climate Impact Assessment (ACIA), in: Encyclopedia of Earth, edited by: Cleveland, C. J., Environmental Information Coalition, National Council for Science and the Environment, Washington, DC, 2010.

Crespo, B. G., Pommier, T., Fernández-Gómez, B., and PedrósAlió, C. Taxonomic composition of the particle attached and free-living bacterial assemblages in the Northwest Mediterranean Sea analyzed by pyrosequencing of the 16S rRNA, FEMS Microbiol. Ecol., in press, doi:10.1111/1574-6941.12130, 2013.

Crump, B. C., Baross, J. A., and Simenstad, C. A.: Dominance of particle-attached bacteria in the Columbia River estuary, USA, Aquat. Microb. Ecol., 14, 7-18, 1998.

Crump, B. C., Armbrust, E. V., and Baross, J. A.: Phylogenetic analysis of particle-attached and free-living bacterial communities in the Columbia river, its estuary, and the adjacent coastal ocean, Appl. Environ. Microbiol., 65, 3192-3204, 1999.

Dittmar, T. and Kattner, G.: The biogeochemistry of the river and shelf ecosystem of the Arctic Ocean: a review, Mar. Chem., 83, 103-120, doi:10.1016/s0304-4203(03)00105-1, 2003.

Doxaran, D., Ehn, J., Bélanger, S., Matsuoka, A., Hooker, S., and Babin, M.: Optical characterisation of suspended particles in the Mackenzie River plume (Canadian Arctic Ocean) and implications for ocean colour remote sensing, Biogeosciences, 9, 32133229, doi:10.5194/bg-9-3213-2012, 2012.

Edgar, R. C.: Search and clustering orders of magnitude faster than BLAST, Bioinformatics, 26, 2460-2461, doi:10.1093/bioinformatics/btq461, 2010.

Eloe, E. A., Shulse, C. N., Fadrosh, D. W., Williamson, S. J., Allen, E. E., and Bartlett, D. H.: Compositional differences in particle-associated and free-living microbial assemblages from an extreme deep-ocean environment, Environ. Microbiol. Rep., 3, 449-458, doi:10.1111/j.1758-2229.2010.00223.x, 2011.

Forest, A., Sampei, M., Makabe, R., Sasaki, H., Barber, D. G., Gratton, Y., Wassmann, P., and Fortier, L.: The annual cycle of particulate organic carbon export in Franklin Bay (Canadian Arctic): Environmental control and food web implications, J. Geophys. Res.-Oceans, 113, C03505, doi:10.1029/2007jc004262, 2008.

Forest, A., Babin, M., Stemmann,L., Picheral, M., Sampei, M., Fortier, L., Gratton, Y., Bélanger, S., Devred, E., Sahlin, J., Doxaran, D., Joux, F., Ortega-Retuerta, E., Jeffrey, W. H., Martín, J., Gasser, B., and Miquel, J. C.: Ecosystem function and particle flux dynamics across the Mackenzie Shelf (Beaufort Sea, Arctic Ocean): an integrative analysis of spatial variability and biophysical forcings, Biogeosciences Discuss., 9, 10883-10960, doi:10.5194/bgd-9-10883-2012, 2012.

Fuchsman, C. A., Kirkpatrick, J. B., Brazelton, W. J., Murray, J. W., and Staley, J. T.: Metabolic strategies of free-living and aggregate-associated bacterial communities inferred from biologic and chemical profiles in the Black Sea suboxic zone, FEMS Microbiol.Ecol., 78, 586-603, 2012.

Galand, P. E., Lovejoy, C., Pouliot, J., Garneau, M. E., and Vincent, W. F.: Microbial community diversity and heterotrophic production in a coastal Arctic ecosystem: A stamukhi lake and its source waters, Limnol. Oceanogr., 53, 813-823, doi:10.4319/lo.2008.53.2.0813, 2008. 
Garneau, M. E., Vincent, W. F., Alonso-Saez,L., Gratton, Y., and Lovejoy, C.: Prokaryotic community structure and heterotrophic production in a river-influenced coastal arctic ecosystem, Aquat. Microb. Ecol., 42, 27-40, doi:10.3354/ame042027, 2006.

Garneau, M. E., Vincent, W. F., Terrado, R., and Lovejoy, C.: Importance of particle-associated bacterial heterotrophy in a coastal Arctic ecosystem, J. Mar. Syst., 75, 185-197, doi:10.1016/j.jmarsys.2008.09.002, 2009.

Ghiglione, J. F. and Murray, A. E.: Pronounced summer to winter differences and higher wintertime richness in coastal Antarctic marine bacterioplankton, Environ. Microbiol., 14, 617-629, doi:10.1111/j.1462-2920.2011.02601.x, 2012.

Ghiglione, J. F., Larcher, M., and Lebaron, P.: Spatial and temporal scales of variation in bacterioplankton community structure in the NW Mediterranean Sea, Aquat. Microb. Ecol., 40, 229-240, doi:10.3354/ame040229, 2005.

Ghiglione, J. F., Mevel, G., Pujo-Pay, M., Mousseau, L., Lebaron, P., and Goutx, M.: Diel and seasonal variations in abundance, activity, and community structure of particle-attached and freeliving bacteria in NW Mediterranean Sea, Microb. Ecol., 54, 217-231, 2007.

Ghiglione, J. F., Palacios, C., Marty, J. C., Mével, G., Labrune, C., Conan, P., Pujo-Pay, M., Garcia, N., and Goutx, M.: Role of environmental factors for the vertical distribution (0-1000 m) of marine bacterial communities in the NW Mediterranean Sea, Biogeosciences, 5, 1751-1764, doi:10.5194/bg-5-1751-2008, 2008.

Ghiglione, J. F., Conan, P., and Pujo-Pay, M.: Diversity of total and active free-living vs. particle-attached bacteria in the euphotic zone of the NW Mediterranean Sea, FEMS Microbiol. Lett., 299, 9-21, doi:10.1111/j.1574-6968.2009.01694.x, 2009.

Ghiglione, J.-F., Galand, P. E., Pommier, T., Pedrós-Alió, C., Maas, E. W., Bakker, K., Bertilson, S., Kirchman, D. L., Lovejoy, C., Yager, P. L., and Murray, A. E.: Pole-to-pole biogeography of surface and deep marine bacterial communities, Proc. Natl. Acad. Sci., 109, 17633-17638, doi:10.1073/pnas.1208160109, 2012.

Gilbert, J. A., Field, D., Swift, P., Newbold, L., Oliver, A., Smyth, T., Somerfield, P. J., Huse, S., and Joint, I.: The seasonal structure of microbial communities in the Western English Channel, Environ. Microbiol., 11, 3132-3139, doi:10.1111/j.14622920.2009.02017.x, 2009.

Ginige, M. P., Hugenholtz, P., Daims, H., Wagner, M., Keller, J., and Blackall, L.L.: Use of stable-isotope probing, fullcycle rRNA analysis, and fluorescence in situ hybridizationmicroautoradiography to study a methanol-fed denitrifying microbial community, Appl. Environ. Microbiol., 70, 588-596, doi:10.1128/aem.70.1.588-596.2004, 2004.

Guo, L. D. and Macdonald, R. W.: Source and transport of terrigenous organic matter in the upper Yukon River: Evidence from isotope (delta C-13, Delta C-14, and delta N-15) composition of dissolved, colloidal, and particulate phases, Glob. Biogeochem. Cy., 20, GB2011, doi:10.1029/2005gb002593, 2006.

Hodges, L. R., Bano, N., Hollibaugh, J. T., and Yager, P. L.: Illustrating the importance of particulate organic matter to pelagic microbial abundance and community structure - an Arctic case study, Aquat. Microb. Ecol., 40, 217-227, doi:10.3354/ame040217, 2005.

Hollibaugh, J. T., Wong, P. S., and Murrell, M. C.: Similarity of particle-associated and free-living bacterial communities in northern San Francisco Bay, California, Aquat. Microb. Ecol., 21, 103-114, doi:10.3354/ame021103, 2000.

Holmfeldt, K., Dziallas, C., Titelman, J., Pohlmann, K., Grossart, H. P., and Riemann, L.: Diversity and abundance of freshwater Actinobacteria along environmental gradients in the brackish northern Baltic Sea, Environ. Microbiol., 11, 2042-2054, doi:10.1111/j.1462-2920.2009.01925.x, 2009.

Huse, S. M., Welch, D. M., Morrison, H. G., and Sogin, M. L.: Ironing out the wrinkles in the rare biosphere through improved OTU clustering, Environ. Microbiol., 12, 1889-1898, doi:10.1111/j.1462-2920.2010.02193.x, 2010.

Ishii, S., Yamamoto, M., Kikuchi, M., Oshima, K., Hattori, M., Otsuka, S., and Senoo, K.: Microbial populations responsive to denitrification-inducing conditions in rice paddy soil, as revealed by comparative $16 \mathrm{~S}$ rRNA gene analysis, Appl. Environ. Microbiol., 75, 7070-7078, doi:10.1128/aem.01481-09, 2009.

Kellogg, C. T. E. and Deming, J. W.: Comparison of free-living, suspended particle, and aggregate-associated bacterial and archaeal communities in the Laptev Sea, Aquat. Microb. Ecol., 57, 1-18, doi:10.3354/ame01317, 2009.

Kellogg, C. T. E., Carpenter, S., Renfro, A., Sallon, A., Michel, C., Cochran, J., and Deming, J.: Evidence for microbial attenuation of particle flux in the Amundsen Gulf and Beaufort Sea: elevated hydrolytic enzyme activity on sinking aggregates, Polar Biol., 34, 2007-2023, 2011.

Kemp, P. F., Lee, S., and Laroche, J.: Estimating the growth rate of slowly-growing marine bacteria from RNA content, Appl. Environ. Microbiol., 59, 2594-2601, 1993.

Kernegger, L., Zweimuller, I., and Peduzzi, P.: Effects of suspended matter quality and virus abundance on microbial parameters: experimental evidence from a large European river, Aquat. Microb. Ecol., 57, 161-173, doi:10.3354/ame01341, 2009.

Lapoussiere, A., Michel, C., Starr, M., Gosselin, M., and Poulin, M.: Role of free-living and particle-attached bacteria in the recycling and export of organic material in the Hudson Bay system, J. Mar. Syst., 88, 434-445, 2011.

Lavoie, D., Denman, K. L., and Macdonald, R. W.: Effects of future climate change on primary productivity and export fluxes in the Beaufort Sea, J. Geophys. Res.-Oceans, 115, C04018, doi:10.1029/2009jc005493, 2010.

Le Fouest, V., Babin, M., and Tremblay, J.-É.: The fate of riverine nutrients on Arctic shelves, Biogeosciences Discuss., 9, 1339713437, doi:10.5194/bgd-9-13397-2012, 2012.

Macdonald, R. W., Solomon, S. M., Cranston, R. E., Welch, H. E., Yunker, M. B., and Gobeil, C.: A sediment and organic carbon budget for the Canadian Beaufort shelf, Mar. Geol., 144, 255273, doi:10.1016/s0025-3227(97)00106-0, 1998.

Martinez-Garcia, M., Brazel, D. M., Swan, B. K., Arnosti, C., Chain, P. S. G., Reitenga, K. G., Xie, G., Poulton, N. J., Gomez, M.L., Masland, D. E. D., Thompson, B., Bellows, W. K., Ziervogel, K., Lo, C. C., Ahmed, S., Gleasner, C. D., Detter, C. J., and Stepanauskas, R.: Capturing single cell genomes of active polysaccharide degraders: an unexpected contribution of Verrucomicrobia, PLoS One, 7, e35314, doi:10.1371/journal.pone.0035314, 2012.

Matsuoka, A., Bricaud, A., Benner, R., Para, J., Sempéré, R., Prieur, L., Bélanger, S., and Babin, M.: Tracing the transport of colored dissolved organic matter in water masses of the Southern Beaufort Sea: relationship with hydrographic characteristics, Biogeo- 
sciences, 9, 925-940, doi:10.5194/bg-9-925-2012, 2012.

Mével, G., Vernet, M., Goutx, M., and Ghiglione, J. F.: Seasonal to hour variation scales in abundance and production of total and particle-attached bacteria in the open NW Mediterranean Sea (0-1000 m), Biogeosciences, 5, 1573-1586, doi:10.5194/bg-51573-2008, 2008.

Murrell, M. C., Hollibaugh, J. T., Silver, M. W., and Wong, P. S.: Bacterioplankton dynamics in northern San Francisco Bay: Role of particle association and seasonal freshwater flow, Limnol. Oceanogr., 44, 295-308, 1999.

Obernosterer, I., Lami, R., Larcher, M., Batailler, N., Catala, P., and Lebaron, P.: Linkage between bacterial carbon processing and the structure of the active bacterial community at a coastal site in the NW Mediterranean Sea, Microb. Ecol., 59, 428-435, doi:10.1007/s00248-009-9588-7, 2010.

Ortega-Retuerta, E., Jeffrey, W., Ghiglione, J., and Joux, F.: Evidence of heterotrophic prokaryotic activity limitation by nitrogen in the Western Arctic Ocean during summer, Polar Biol., 35, 785-794, 2012a.

Ortega-Retuerta, E., Jeffrey, W. H., Babin, M., Bélanger, S., Benner, R., Marie, D., Matsuoka, A., Raimbault, P., and Joux, F.: Carbon fluxes in the Canadian Arctic: patterns and drivers of bacterial abundance, production and respiration on the Beaufort Sea margin, Biogeosciences, 9, 3679-3692, doi:10.5194/bg-9-36792012, 2012b.

Perovich, D. K.: The changing Arctic sea ice cover, Oceanography, 24, 162-173, 2011.

Peterson, B. J., Holmes, R. M., McClelland, J. W., Vorosmarty, C. J., Lammers, R. B., Shiklomanov, A. I., Shiklomanov, I. A., and Rahmstorf, S.: Increasing river discharge to the Arctic Ocean, Science, 298, 2171-2173, doi:10.1126/science.1077445, 2002.

Quince, C., Lanzen, A., Davenport, R. J., and Turnbaugh, P. J.: Removing noise from pyrosequenced amplicons, BMC Bioinformatics, 12, 38, doi:10.1186/1471-2105-12-38, 2011.

Rath, J., Wu, K. Y., Herndl, G. J., and DeLong, E. F.: High phylogenetic diversity in a marine-snow-associated bacterial assemblage, Aquat. Microb. Ecol., 14, 261-269, doi:10.3354/ame014261, 1998.

Riemann, L. and Middelboe, M.: Stability of bacterial and viral community compositions in Danish coastal waters as depicted by DNA fingerprinting techniques, Aquat. Microb. Ecol., 27, 219232, doi:10.3354/ame027219, 2002.

Rontani, J.-F., Charriere, B., Forest, A., Heussner, S., Vaultier, F., Petit, M., Delsaut, N., Fortier, L., and Sempéré, R.: Intense photooxidative degradation of planktonic and bacterial lipids in sinking particles collected with sediment traps across the Canadian Beaufort Shelf (Arctic Ocean), Biogeosciences, 9, 4787-4802, doi:10.5194/bg-9-4787-2012, 2012.

Shen, Y., Fichot, C. G., and Benner, R.: Dissolved organic matter composition and bioavailability reflect ecosystem productivity in the Western Arctic Ocean, Biogeosciences, 9, 4993-5005, doi:10.5194/bg-9-4993-2012, 2012.
Smith, D. C. and Azam, F.: A simple, economical method for measuring bacterial protein synthesis rates in seawater using $3 \mathrm{H}-$ leucine, Mar. Microb. Food Webs, 6, 107-114, 1992.

Smith, D. C., Simon, M., Alldredge, A.L., and Azam, F.: Intense hydrolytic enzyme-activity on marine aggregates and implications for rapid particle dissolution, Nature, 359, 139-142, doi:10.1038/359139a0, 1992.

Sogin, M.L., Morrison, H. G., Huber, J. A., Mark Welch, D., Huse, S. M., Neal, P. R., Arrieta, J. M., and Herndl, G. J.: Microbial diversity in the deep sea and the underexplored "rare biosphere", Proc. Natl. Acad. Sci. USA, 103, 12115-12120, doi:10.1073/pnas.0605127103, 2006.

Sun, Y., Wolcott, R. D., and Dowd, S. E.: Tag-encoded FLX amplicon pyrosequencing for the elucidation of microbial and functional gene diversity in any environment, Methods Mol. Biol., 733, 129-141, 2011.

Tremblay, J. E. and Gagnon, J.: The effects of irradiance and nutrient supply on the productivity of Arctic waters: A perspective on climate change, in: Influence of Climate Change on the Changing Arctic and SubArctic Conditions, edited by: Nihoul, J. C. J. and Kostianoy, A. G., Springer, Dordrecht, Netherlands, 73-93, 2009.

Troussellier, M., Schafer, H., Batailler, N., Bernard,L., Courties, C., Lebaron, P., Muyzer, G., Servais, P., and Vives-Rego, J.: Bacterial activity and genetic richness along an estuarine gradient (Rhone River plume, France), Aquat. Microb. Ecol., 28, 13-24, doi:10.3354/ame028013, 2002.

Vallieres, C., Retamal, L., Ramlal, P., Osburn, C.L., and Vincent, W. F.: Bacterial production and microbial food web structure in a large arctic river and the coastal Arctic Ocean, J. Mar. Sys, 74, 756-773, doi:10.1016/j.jmarsys.2007.12.002, 2008.

Wang, Q., Garrity, G. M., Tiedje, J. M., and Cole, J. R.: Naive Bayesian classifier for rapid assignment of rRNA sequences into the new bacterial taxonomy, Appl. Environ. Microbiol., 73, 5261-5267, doi:10.1128/aem.00062-07, 2007.

Wassmann, P., Duarte, C. M., Agusti, S., and Sejr, M. K.: Footprints of climate change in the Arctic marine ecosystem, Glob. Change Biol., 17, 1235-1249, doi:10.1111/j.1365-2486.2010.02311.x, 2011.

Williams, T. J., Long, E., Evans, F., Demaere, M. Z., Lauro, F. M., Raftery, M. J., Ducklow, H., Grzymski, J. J., Murray, A. E., and Cavicchioli, R.: A metaproteomic assessment of winter and summer bacterioplankton from Antarctic Peninsula coastal surface waters, ISME J., 6, 1883-1900, doi:10.1038/ismej.2012.28, 2012.

Wozniak, S. B., Stramski, D., Stramska, M., Reynolds, R. A., Wright, V. M., Miksic, E. Y., Cichocka, M., and Cieplak, A. M.: Optical variability of seawater in relation to particle concentration, composition, and size distribution in the nearshore marine environment at Imperial Beach, California, J. Geophys Res.-Oceans, 115, C08027, doi:10.1029/2009JC005554, 2010. 